УДК 631.5:635.657

(C) 2012

Каленська С. М., доктор сільськогосподарських наук, професор, член-кореспондент НААН Украӥни, Новицька Н. В., кандидат сільськогосподарських наук, Нетупська I. T., аспірант * Національний університет біоресурсів і природокористування України

\title{
ФОРМУВАННЯ ВРОЖАЮ НУТУ ПІД ВПЛИВОМ ЕЛЕМЕНТІВ ТЕХНОЛОГІЇ ВИРОЩУВАННЯ
}

\section{Рецензент - кандидат сільськогосподарських наук В. М. Рожко}

\begin{abstract}
Висвітлено господарське та агротехнічне значення найпоширенішої зернобобової культури нут, а також позитивну дію для трунтів, на яких розміщують дану культуру в сівозміні. Відображено корисний вплив мінеральних добрив та передпосівної інокуляції насіння на формування врожаю. Наведено результати досліджень впливу елементів технології вирошування на формування структурних елементів і врожайності досліджуваних сортів Розанна, Тріумф та Пегас на чорноземах типових. Встановлено, щзо передпосівна інокуляція насіння у комплексі з невисокими дозами азотних добрив сприяли приросту врожаю сортів нуту. Найвищу урожайність нуту у досліді $(4,9 \mathrm{~m} / \mathrm{za})$ відмічено в сорту Розанна у варіанті із застосуванням передпосівної інокуляиї насіння на фоні внесення $N_{30} P_{60} K_{60}$.
\end{abstract}

Ключові слова: Cicer arietinum L., мінеральні добрива, передпосівна інокуляція, структурні елементи врожаю, маса 1000 насінин, врожсайність.

Постановка проблеми. Нут - одна 3 найдавніших і найпоширеніших зернобобових культур, яка використовується в усьому світі на харчові й кормові цілі. Поєднання найвищої з-поміж зернобобових культур за посухо-, жаро- та холодостійкістю робить цю культуру унікальною, поскільки вона спроможна давати економічно обгрунтований урожай насіння у спекотних і посушливих регіонах світу. Насіння нуту містить значну кількість повноцінного білка, жиру, вуглеводів, а також багато ферментів, мінеральних та органічних речовин. Дана культура може внести суттєву частку в розв'язання проблеми білка й значно поповнити продовольчі ресурси планети. Як зернобобова культура нут у симбіозі 3 азотфіксуючими бактеріями здатна засвоювати азот 3 атмосфери, задовольняючи себе цим елементом і залишаючи наступним культурам через рослинні рештки чималу кількість біологічно засвоєного азоту. Урожайність найціннішої зернової культури - пшениці озимої - після нуту така ж, як і після чорного пару, а в окремі роки навіть набагато вища.

Аналіз основних досліджень і публікацій, у яких започатковано розв'язання проблеми. Останнім часом в Україні, як свідчить огляд спеціальних джерел, спостерігається зростання зацікавленості сільгоспвиробників до цієї культури і збільшення попиту на неї на світовому ринку $[2,3,7]$.

Сільськогосподарська практика вимагає наразі однозначної відповіді на питання: бобові культури потребують азотного удобрення чи мають рацію ті дослідники, які стверджують, що мінеральний азот пригнічує симбіотичну азотфіксацію бобових культур, тому економічно вигідніше такі рослини не удобрювати. Дослідники Московської сільськогосподарської академії ім. Тімірязєва провели досліди, результати яких дали можливість отримати картину поведінки симбіонтів в умовах вегетаційних і польових дослідів за забезпечення рослин різними дозами азотних добрив. Було встановлено, що підвищення вмісту розчинних азотовмісних з'єднань у середовищі в польових умовах за оптимальних умов вирощування рослин не перешкоджає іх симбіозу із бульбочковими бактеріями. Зниження частки атмосферного азоту, який засвоюють рослини за підвищеної забезпеченості мінеральним азотом, має лише відносний характер $[1,8,9]$.

Суттєвими важелями збільшення виробництва продукції нуту є: виведення та впровадження у виробництво високопродуктивних вітчизняних сортів, реалізація сучасних технологій вирощування та переробки зерна, а також покращання насінництва. Дані питання у практиці вирощування нуту все ще потребують свого вирішення [2].

Мета досліджень. Вивчення впливу мінерального живлення і передпосівної обробки насіння штамами бульбочкових бактерій (нутовий нітрагін) відповідних сортів на формування структури врожаю та біологічну врожайність нуту.

* Керівник-доктор сільськогосподарських наук, професор С. М. Каленська 
Матеріали і методи досліджень. Польові дослідження проводили в 2010-2011 рр. на полях кафедри рослинництва у ВП НУБіП України «Агрономічна дослідна станція». Нут висівали на чорноземах типових за температури грунту на глибині загортання насіння $8-10{ }^{\circ} \mathrm{C}$ сівалкою «Клен». Площа елементарної ділянки $-42 \mathrm{~m}^{2}$; облікова площа $-28,8 \mathrm{~m}^{2}(3,2 \times 9)$. Повторність досліду - чотириразова [5].

У дослідженнях використовували загальноприйняті в рослинництві та землеробстві методики $[4,6]$. У дослідах на вивчення були поставлені середньостиглі сорти нуту вітчизняної селекції: Тріумф, Розанна та Пегас. Мінеральні добрива вносили під основний обробіток грунту та під весняну культивацію, використовуючи наступні схеми досліджень: 1 - контроль (без добрив); 2 - NPK 30:60:60; 3 - NPK - 60:60:60; 4 - NPK - 90:60:60, 5 - NPK - 120:60:60, 6 - NPK - 150:60:60. Форми добрив - аміачна селітра (N - $30 \%)$, гранульований суперфосфат $\left(\mathrm{P}_{2} \mathrm{O}_{5}-19 \%\right)$ і калійна сіль $\left(\mathrm{K}_{2} \mathrm{O}\right.$ - 40 \%). Варіанти досліджень включали також використання нутового нітрагіну (обробка насіннєвого матеріалу бульбочковими бактеріями). Замочували 3 розрахунку 1,5 л робочим розчином на 150 кг насіння нуту в день сівби.

Результати досліджень. Формування врожаїв зерна сільськогосподарських культур суттєво залежить від грунтово-кліматичних умов вирощування, а також від рівня родючості грунту. Тому для організації стабільного виробництва нуту в зонах із нестійкими факторами довкілля необхідно висівати сорти, здатні за різних погодних умов і на різних фонах забезпечити отримання стабільних урожаїв, що досягається завдяки їх реакції на умови вирощування [9].

Проведені нами дослідження грунтуються на таких факторах впливу, як удобрення та застосування передпосівної інокуляції на сорти Розанна, Тріумф і Пегас. Результати структурного аналізу, подані у таблиці, дають змогу проаналізувати вплив елементів технології вирощування на структурні елементи рослин нуту у 2010-2011 роках. Важливим показником придатності конкретного сорту нуту до механізованого збирання $\epsilon$ висота кріплення нижніх бобів на рослинах, оскільки саме в нижніх бобах (які закладаються першими) формується найбільш крупне, повноцінне за посівними якостями насіння. Особливістю нуту полягає в тому, що майже всі сорти мають порівняно високе кріплення нижніх бобів (близько 20 см), тому нут придатний для механізованого збирання без зайвих втрат [2].

У наших дослідженнях висота кріплення ниж- ніх бобів у сорту Розанна у варіанті без інокуляції насіння варіювала від 20,6 см (без удобрення) до 21,6 см $\left(\mathrm{N}_{60} \mathrm{P}_{60} \mathrm{~K}_{60}\right)$, у сорту Тріумф - від 19,4 см (за $\mathrm{N}_{30}$ та $\mathrm{N}_{90}$ на фоні $\mathrm{P}_{60} \mathrm{~K}_{60}$ ) до $21,7 \mathrm{~cm}$ $\left(\mathrm{N}_{60} \mathrm{P}_{60} \mathrm{~K}_{60}\right)$, у сорту Пегас - від 17,9 (контроль) до $20,3\left(\mathrm{~N}_{60} \mathrm{P}_{60} \mathrm{~K}_{60}\right)$. У варіанті з інокуляцією насіння у сорту Розанна даний показник зріс порівняно з варіантом без інокуляції на 1,3-1,5 см: у сорту Тріумф - на $0,6-0,7$ см, у сорту Пегас на 0,2-1,6 см. Найвищий показник висоти кріплення нижніх бобів відмічено у сорту Розанна у варіанті 3 інокуляцією насіння та за внесення $\mathrm{N}_{60} \mathrm{P}_{60} \mathrm{~K}_{60}(23,1 \mathrm{~cm})$, а найнижчий $(17,9 \mathrm{~cm})-$ у сорту Пегас у варіанті з абсолютним контролем.

Кількість бобів на рослині та кількість насінин у бобі - важливий елемент структури врожаю, що обумовлює продуктивність рослини і бере участь у формуванні врожаю. Збільшення норм внесення азотних добрив на фоні фосфорнокалійних у цілому сприяло збільшенню кількості бобів на рослині. Максимальна кількість бобів у сорту Розанна у варіанті без інокуляції спостерігалася за внесення добрив $\mathrm{N}_{60} \mathrm{P}_{60} \mathrm{~K}_{60}(39,4$ шт.), тоді як на варіанті без внесення добрив даний показник становив 24,0 шт. Збільшення азотних добрив до $\mathrm{N}_{150}$ призвело до зниження даного показника до 26,6 штук. У сортів Тріумф та Пегас відмічали аналогічну тенденцію. У сорту Тріумф найвищий показник склав 35,8 шт. $\left(\mathrm{N}_{60} \mathrm{P}_{60} \mathrm{~K}_{60}\right)$, а найнижчий - 27,3 (без удобрення), у сорту Пегас, відповідно, 34,5 шт. $\left(\mathrm{N}_{60} \mathrm{P}_{60} \mathrm{~K}_{60}\right)$ та 24,3 шт. (без удобрення). Застосування передпосівної інокуляції на фоні мінерального удобрення, в свою чергу, також сприяло збільшенню кількості бобів на рослині. При цьому у сорту Розанна цей показник досяг найвищої відмітки за внесення $\mathrm{N}_{30} \mathrm{P}_{60} \mathrm{~K}_{60}$ і становив 47,6 шт., найнижчий результат спостерігали за внесення $\mathrm{N}_{150} \mathrm{P}_{60} \mathrm{~K}_{60}$ (35,5 шт.). У сорту Тріумф, відповідно, 41,1 шт. $\left(\mathrm{N}_{30} \mathrm{P}_{60} \mathrm{~K}_{60}\right)$ та 29,9 шт. $\left(\mathrm{N}_{150} \mathrm{P}_{60} \mathrm{~K}_{60}\right)$. У сорту Пегас $-40,0$ шт. $\left(\mathrm{N}_{30} \mathrm{P}_{60} \mathrm{~K}_{60}\right)$ та 23,9 шт. $\left(\mathrm{N}_{150} \mathrm{P}_{60} \mathrm{~K}_{60}\right)$. Таким чином, можна констатувати, що у варіанті з інокуляцією насіння збільшення норм азотних добрив від $\mathrm{N}_{60} \mathrm{P}_{60} \mathrm{~K}_{60}$ до $\mathrm{N}_{150} \mathrm{P}_{60} \mathrm{~K}_{60}$ призводить до зниження кількості бобів на рослині в усіх досліджуваних сортів.

Схожа тенденція виявлена нами й за вивчення впливу досліджуваних факторів на кількість насінин на рослині. Встановлено, що зі збільшенням кількості азотних добрив до певної межі (до $\mathrm{N}_{60}$ ) у варіанті без інокуляції збільшувалась і кількість насіння на рослині. Максимальний показник у сорту Розанна було отримано за внесення $\mathrm{N}_{60}-47,8$ шт. насінин, тоді як у варіанті 


\section{СІЛЬСЬКЕ ГОСПОДАРСТВО. РОСЛИННИЦТВО}

без добрив - 32,1 штук. Аналогічно і в сортів Тріумф та Пегас - 36,0 та 48,2 шт. проти 26,8 та 29,5 шт. відповідно. Обробка насіння нутовим нітрагіном сприяла збільшенню кількості насінин на рослині. У сорту Розанна даний показник варіював від найменшого показника за внесення $\mathrm{N}_{150} \mathrm{P}_{60} \mathrm{~K}_{60}-31,1$ шт. до максимальної кількості за внесення $\mathrm{N}_{30} \mathrm{P}_{60} \mathrm{~K}_{60}-52,3$ шт., у сорту Тріумф - від 31,7 до 44,0 шт. та у сорту Пегас - від 33,8 до 51,3 шт. відповідно.
Застосування мінеральних добрив позитивно впливало на масу 1000 насінин у трьох досліджуваних сортів. У сорту Розанна у варіанті без інокуляції збільшення азотних добрив на фоні $\mathrm{P}_{60} \mathrm{~K}_{60}$ до $\mathrm{N}_{60}$ сприяло збільшенню даного показника до 294,9 г за 286,6 г у варіанті без добрив. У сорту Тріумф, відповідно, 398,7 г за 389,1 г (без удобрення), у сорту Пегас - 298,5 г за 289,3 г (без удобрення). Подальше збільшення норми азотних добрив до $\mathrm{N}_{150} \mathrm{P}_{60} \mathrm{~K}_{60}$ призводило до

Структура врожаю нуту залежно від інокуляції та удобрення, (2010-2011 рр.)

\begin{tabular}{|c|c|c|c|c|c|c|c|}
\hline Сорт & $\begin{array}{c}\text { Варіант удобрення } \\
\text { та інокуляції насіння }\end{array}$ & $\begin{array}{c}\text { Висота } \\
\text { кріплення } \\
\text { нижніх } \\
\text { бобів, см }\end{array}$ & $\begin{array}{l}\text { Довжина } \\
\text { бобів, см }\end{array}$ & $\begin{array}{c}\text { Кількість } \\
\text { бобів, шт. } \\
\text { на } 1 \\
\text { рослині }\end{array}$ & $\begin{array}{c}\text { Кількість } \\
\text { насінин } \\
\text { на росли- } \\
\text { ні, шт. }\end{array}$ & $\begin{array}{c}\text { Маса } \\
\text { насіння } 3 \\
\text { рослини, Г }\end{array}$ & $\begin{array}{c}\text { Маса } \\
1000 \\
\text { насінин, г }\end{array}$ \\
\hline \multirow{12}{*}{ 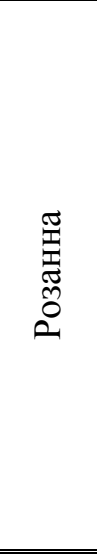 } & Контроль & 20,6 & 2,3 & 24,0 & 32,1 & 9,0 & 286,6 \\
\hline & Контроль + інокуляція & 21,9 & 2,3 & 44,2 & 47,8 & 10,1 & 292,2 \\
\hline & $\mathrm{N}_{30} \mathrm{P}_{60} \mathrm{~K}_{60}$ & 21,2 & 2,4 & 32,6 & 37,3 & 10,3 & 293,9 \\
\hline & $\mathrm{N}_{30} \mathrm{P}_{60} \mathrm{~K}_{60}+$ інокуляція & 22,7 & 2,4 & 47,6 & 52,3 & 10,5 & 296,9 \\
\hline & $\mathrm{N}_{60} \mathrm{P}_{60} \mathrm{~K}_{60}$ & 21,6 & 2,3 & 39,4 & 47,8 & 10,1 & 294,9 \\
\hline & $\mathrm{N}_{60} \mathrm{P}_{60} \mathrm{~K}_{60}+$ інокуляція & 23,1 & 2,2 & 47,4 & 50,4 & 10,3 & 296,6 \\
\hline & $\mathrm{N}_{90} \mathrm{P}_{60} \mathrm{~K}_{60}$ & 20,8 & 2,3 & 29,2 & 40,8 & 9,7 & 294,0 \\
\hline & $\mathrm{N}_{90} \mathrm{P}_{60} \mathrm{~K}_{60}+$ інокуляція & 22,3 & 2,5 & 40,1 & 47,0 & 10,4 & 296,0 \\
\hline & $\mathrm{N}_{120} \mathrm{P}_{60} \mathrm{~K}_{60}$ & 21,2 & 2,4 & 28,1 & 37,1 & 9,8 & 289,5 \\
\hline & $\mathrm{N}_{120} \mathrm{P}_{60} \mathrm{~K}_{60}+$ інокуляція & 22,3 & 2,4 & 36,2 & 40,8 & 10,3 & 294,4 \\
\hline & $\mathrm{N}_{150} \mathrm{P}_{60} \mathrm{~K}_{60}$ & 21,3 & 2,4 & 26,6 & 36,5 & 9,3 & 289,1 \\
\hline & $\mathrm{N}_{150} \mathrm{P}_{60} \mathrm{~K}_{60}+$ інокуляція & 22,1 & 2,5 & 35,5 & 31,1 & 9,8 & 288,7 \\
\hline \multirow{12}{*}{ 吝 } & Контроль & 19,7 & 2,4 & 27,3 & 26,8 & 10,2 & 389,1 \\
\hline & Контроль + інокуляція & 20,1 & 2,6 & 35,8 & 38,4 & 11,0 & 399,4 \\
\hline & $\mathrm{N}_{30} \mathrm{P}_{60} \mathrm{~K}_{60}$ & 19,4 & 2,4 & 31,4 & 27,9 & 11,6 & 395,4 \\
\hline & $\mathrm{N}_{30} \mathrm{P}_{60} \mathrm{~K}_{60}+$ інокуляція & 20,7 & 2,7 & 41,1 & 44,0 & 11,2 & 405,8 \\
\hline & $\mathrm{N}_{60} \mathrm{P}_{60} \mathrm{~K}_{60}$ & 21,7 & 2,6 & 35,8 & 36,0 & 11,3 & 398,7 \\
\hline & $\mathrm{N}_{60} \mathrm{P}_{60} \mathrm{~K}_{60}+$ інокуляція & 22,4 & 2,7 & 36,0 & 38,5 & 11,4 & 404,5 \\
\hline & $\mathrm{N}_{90} \mathrm{P}_{60} \mathrm{~K}_{60}$ & 19,4 & 2,4 & 34,3 & 34,1 & 10,9 & 397,3 \\
\hline & $\mathrm{N}_{90} \mathrm{P}_{60} \mathrm{~K}_{60}+$ інокуляція & 21,5 & 2,5 & 33,0 & 37,3 & 11,4 & 401,5 \\
\hline & $\mathrm{N}_{120} \mathrm{P}_{60} \mathrm{~K}_{60}$ & 19,8 & 2,4 & 33,5 & 32,6 & 11,2 & 396,4 \\
\hline & $\mathrm{N}_{120} \mathrm{P}_{60} \mathrm{~K}_{60}+$ інокуляція & 20,2 & 2,6 & 32,2 & 34,7 & 11,3 & 399,8 \\
\hline & $\mathrm{N}_{150} \mathrm{P}_{60} \mathrm{~K}_{60}$ & 20,1 & 2,4 & 29,7 & 27,5 & 10,7 & 395,2 \\
\hline & $\mathrm{N}_{150} \mathrm{P}_{60} \mathrm{~K}_{60}+$ інокуляція & 20,0 & 2,4 & 29,9 & 31,7 & 10,6 & 397,7 \\
\hline \multirow{12}{*}{ 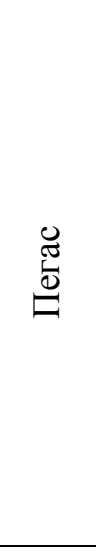 } & Контроль & 17,9 & 1,6 & 24,3 & 29,5 & 11,3 & 289,3 \\
\hline & Контроль + інокуляція & 18,1 & 1,6 & 35,4 & 40,0 & 11,7 & 299,6 \\
\hline & $\mathrm{N}_{30} \mathrm{P}_{60} \mathrm{~K}_{60}$ & 18,4 & 1,7 & 29,2 & 34,4 & 12,2 & 295,7 \\
\hline & $\mathrm{N}_{30} \mathrm{P}_{60} \mathrm{~K}_{60}+$ інокуляція & 18,8 & 1,5 & 40,0 & 51,3 & 11,9 & 302,8 \\
\hline & $\mathrm{N}_{60} \mathrm{P}_{60} \mathrm{~K}_{60}$ & 20,3 & 1,9 & 34,5 & 48,2 & 12,1 & 298,5 \\
\hline & $\mathrm{N}_{60} \mathrm{P}_{60} \mathrm{~K}_{60}+$ інокуляція & 21,9 & 1,6 & 34,3 & 45,8 & 11,9 & 301,4 \\
\hline & $\mathrm{N}_{90} \mathrm{P}_{60} \mathrm{~K}_{60}$ & 19,9 & 1,8 & 31,1 & 44,4 & 10,3 & 298,3 \\
\hline & $\mathrm{N}_{90} \mathrm{P}_{60} \mathrm{~K}_{60}+$ інокуляція & 20,1 & 1,8 & 31,0 & 44,1 & 10,6 & 301,2 \\
\hline & $\mathrm{N}_{120} \mathrm{P}_{60} \mathrm{~K}_{60}$ & 18,2 & 1,8 & 30,0 & 36,0 & 10,7 & 294,4 \\
\hline & $\mathrm{N}_{120} \mathrm{P}_{60} \mathrm{~K}_{60}+$ інокуляція & 18,5 & 1,6 & 28,2 & 38,7 & 10,5 & 298,9 \\
\hline & $\mathrm{N}_{150} \mathrm{P}_{60} \mathrm{~K}_{60}$ & 18,0 & 1,7 & 25,0 & 32,2 & 10,3 & 293,1 \\
\hline & $\mathrm{N}_{150} \mathrm{P}_{60} \mathrm{~K}_{60}+$ інокуляція & 18,3 & 1,6 & 23,9 & 33,8 & 10,0 & 298,6 \\
\hline
\end{tabular}




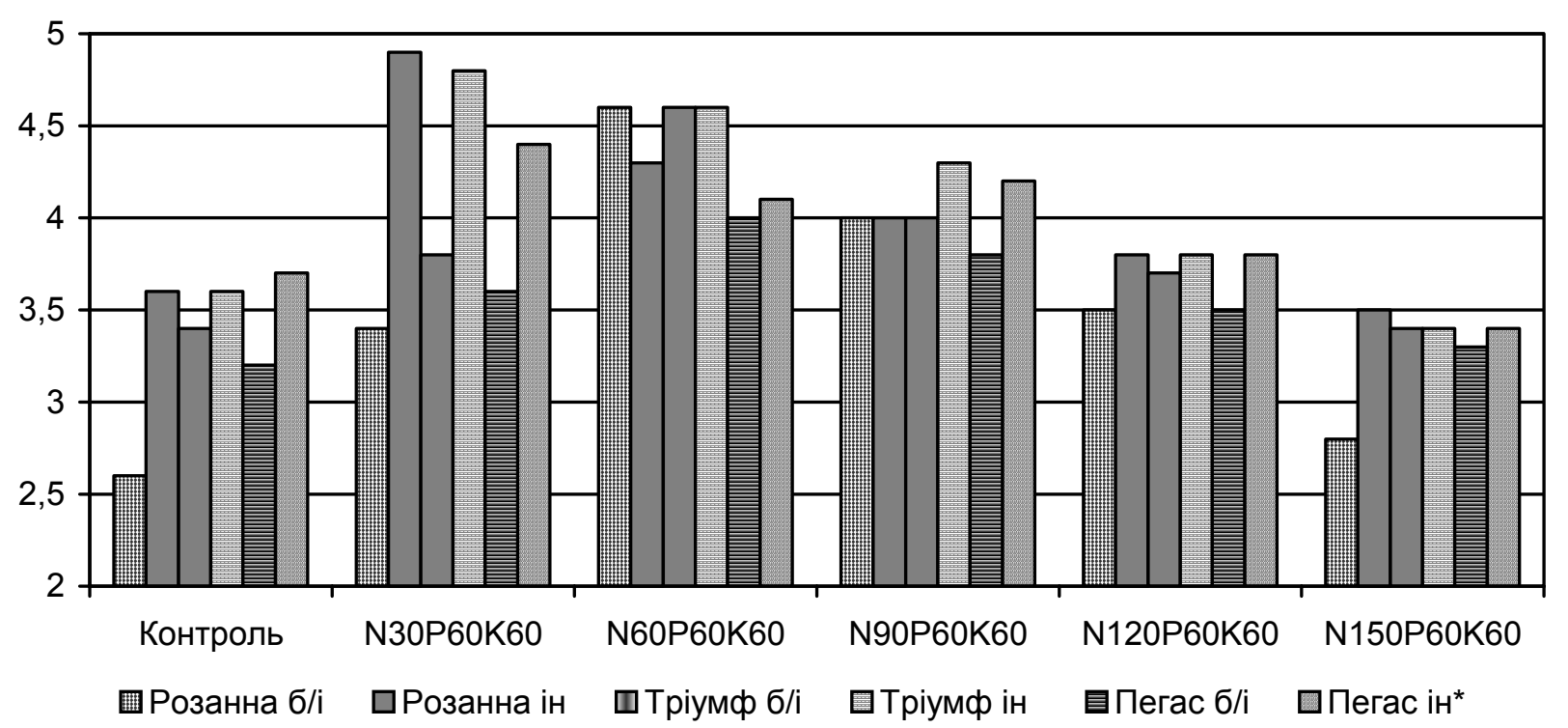

Рис. Врожсайність досліджуваних сортів нуту, m/2а (2010-2011 рр.)

* Примітка: б/i - без застосування інокуляції насіння; ін - із застосуванням передпосівної інокуляції насіння

зниження маси 1000 насінин у сортів: Розанни 289,1 г, Тріумф - 395,2 г, Пегас - 293,1 г. У варіанті із застосуванням інокуляції насіння у сортів Розанна, Тріумф та Пегас найвищий показник маси 1000 насінин відмічено за внесення добрив у кількості $\mathrm{N}_{30} \mathrm{P}_{60} \mathrm{~K}_{60}(296,9 ; 405,8$ та 302,8 г відповідно), а найнижчий $(288,7 ; 397,7$ та 298,6 г) за внесення $\mathrm{N}_{150} \mathrm{P}_{60} \mathrm{~K}_{60}$.

Формування врожаю трьох досліджуваних сортів нуту суттєво залежало від погодних умов за роки вирощування, однак досліджувані фактори впливу (добрива, інокуляція насіння) також сприяли певній тенденції збільшення врожаю (див. рис.). Так, у всіх трьох сортів на фоні удобрення $\mathrm{N}_{60} \mathrm{P}_{60} \mathrm{~K}_{60}$ У варіанті без інокуляції насіння виявлено помітний приріст врожаю порівняно з результатами, отриманими на контролі. Урожайність сорту Розанна за удобрення $\mathrm{N}_{60} \mathrm{P}_{60} \mathrm{~K}_{60}$ становила 4,6 т/га, у той час як на контролі цей показник становив 2,6 т/га; сорту Тріумф - 4,6 т/га при 3,4 т/га (контроль); сорту Пегас - 4,0 т/га при 3,2 т/га. Подальше збільшення норм азотних добрив призвело до зниження виходу насіння з однієї рослини й, відповідно, урожайності сортів Розанна, Тріумф та Пегас до 2,8; 3,4 та 3,3 т/га. Водночас, позитивний вплив мала й обробка насіння нутовим нітрагіном на фо-

\section{БІБЛІОГРАФІЯ}

1. Бобро М. А. Оптимізація технології вирощування зернових і бобових культур / Бобро М. А., Головченко Б. Х. // Современные технологии, ні мінеральних добрив.

Помітний приріст урожаю сортів Розанна, Тріумф і Пегас у досліді із застосуванням інокуляції насіння відмічено на фоні добрив $\mathrm{N}_{30} \mathrm{P}_{60} \mathrm{~K}_{60}$, що становив 4,9; 4,8 та 4,4 т/га відповідно. Подальше збільшення норм азотних добрив до $\mathrm{N}_{150}$ Hа фоні $\mathrm{P}_{60} \mathrm{~K}_{60}$ при застосуванні інокуляції насіння призвело до зниження даного показника (до 3,5 ; 3,4 та 3,4 т/га відповідно).

Висновки. Збільшення норм внесення азотних добрив позитивно впливає на формування елементів структури врожаю нуту до певної межі, зокрема, збільшення норм азотних добрив до $\mathrm{N}_{60}$ на фоні $\mathrm{P}_{60} \mathrm{~K}_{60}$ сприяє збільшенню всіх показників у структурі врожаю, проте подальше збільшення норм добрив до $\mathrm{N}_{150}$ призводить до зниження даних показників сортів Розанна, Тріумф та Пегас даної культури. Застосування інокуляції насіння сприяло одержанню значних приростів урожайності зерна досліджуваної культури. Найбільшу в досліді врожайність нуту $(4,9$ т/га) одержали у сорту Розанна на варіанті із застосуванням передпосівної інокуляції насіння нутовим нітрагіном на фоні внесення $\mathrm{N}_{30} \mathrm{P}_{60} \mathrm{~K}_{60}$, а найменшу $(2,6$ т/га) отримали у цього ж сорту на варіанті з абсолютним контролем.

экономика и эколгия в промышленности, на транспорте и в сельском хозяйстве : Сб. науч. статей по материалам 5-й Международной науч- 
но-метод. конф. - К. : ИСМО, Алциста, 1997. $317 \mathrm{c}$.

2. Бушулян О. В., Січкар В. I. Нут: генетика, селекція, насінництво, технологія вирощування : Монографія. - Одеса, 2009. - 248 с.

3. Дідович С. В., Портянко С. І., Дідович О. М. Вплив мінерального азоту на ефективність симбіозу нуту (Cicer arietinum L.) 3 Mesorhizobium ciceri // Тези наук. конф. молодих учених (Ужгород, 1-3 грудня 2005 р.). - Ужгород, 2005. C. $48-49$.

4. Довідник з вирощування зернових та зернобобових культур / [В. В. Лихочвор, М. І. Бомба, С. В. Дубковецький та ін.]. - Львів : Українські технології, 1999. - 408 с.

5. Доспехов Б. А. Методика полевого опыта (с основами статистической обработки результатов исследований). - М. : Агропромиздат, 1985.
$-351 \mathrm{c}$.

6. Методика Державного сортовипробування с.-г. культур. Вип. другий / За ред. В. В. Вовкодава. - К., 2001. - 65 с.

7. Сичкарь В.И., Бушулян О. В., Толкачёв Н. 3. Нут. Биологические особенности, технология выращивания и новые сорта. - Одесса : СГИНАЦ СЕИС, 2004. $-20 \mathrm{c}$.

8. Старченков Е.П. Изучение физиологобиохимических и генетических процессов фиксации азота бобовыми растениями // Тез. докл. коллок. по азотфиксации, посвящ. памяти чл.кор. РАН В. Л. Кретовича (Москва, 24-26 янв., 1995). - Пущино, 1995. - С. 33.

9. Шnаар Д., Эллмер Ф., Постников А [и др.]. Зернобобовые культуры / Под общей редакцией Д. Шпаара. - Мн. : ФУАинформ, 2000. - 264 с. 